\title{
Processing and food uses of bananas and plantains in Cameroon
}

\author{
Gérard NGOH NEWILAH $^{a *}$, Jean TCHANGO TCHANGO ${ }^{a}$, Élie FOKOU ${ }^{b}$, François-Xavier ETOA ${ }^{b}$
}

a CARBAP, PO Box 832, Douala, Cameroon gbngoh@yahoo.com

b University of Yaoundé I, PO Box 812, Yaoundé, Cameroon

${ }^{*}$ Correspondence and reprints

Fruits, 2005, vol. 60, p. 245-253 (C) 2005 Cirad/EDP Sciences All rights reserved DOI: 10.1051/fruits:2005031

RESUMEN EsPAÑOL, p. 253

\section{Processing and food uses of bananas and plantains in Cameroon.}

Abstract - Introduction. In Southern Cameroon, bananas and plantains (Musa) play an important role in the population's diet. There are many food uses of these crops relative to the eating habits of consumers. Our study was carried out in order to list the varieties of bananas and plantains mostly used by housewives and restaurant dealers and to describe the various culinary preparations used for their transformation. Methods. The processing and culinary methods of bananas and plantains, including the estimation as well as the measurement of the quantities of ingredients used, and the traditional utilisations of these foodstuffs, were investigated in two Cameroonian towns (Bafoussam and Yaoundé). Results. Some culinary preparations using different varieties are common in Southern Cameroon such as roasted or fried plantain, plantain chips, boiled plantain or banana and pounded plantain. They are eaten with various sauces, vegetables and other food complements. Other preparations found in these regions include stuffed plantain or banana, plantain or banana porridges and traditional recipes called kondre and malaxé. Preparation of chips, fried and roasted plantain are mainly carried out by women and young boys on the streets in an effort to diversify sources of income. These various transformation and uses of bananas and plantains contribute to the reduction of post-harvest losses as well as the valorisation of these perishable food stuffs. Conclusion. The evaluation of their nutrient composition (macro- and micronutrients) as well as the effects of culinary preparations and the bio-availability of those nutrients are being conducted at the CARBAP Post-Harvest Technology Laboratory in order to appreciate their contribution in the fight against malnutrition in some regions of Cameroon.

Cameroon / Musa (bananas) / Musa (plantains) / post-harvest technology / food technology / cooking / feeding habits / feeding preferences / processing / ingredients

\section{Transformations et utilisations alimentaires des bananes et des plantains au Cameroun.}

Résumé - Introduction. Dans le sud du Cameroun, les bananes et les plantains (Musa) jouent un rôle important dans le régime alimentaire des populations. Il existe une grande diversité de préparation de ces produits en fonction des habitudes alimentaires des consommateurs. Notre étude visait à inventorier les variétés de bananes et de plantains les plus employées par les femmes au foyer et les restaurateurs, et à décrire les diverses préparations culinaires utilisées pour la transformation de leurs fruits. Méthodes. Les transformations des bananes et plantains et les techniques culinaires incluant aussi bien la nature des ingrédients utilisés que leurs quantités, de même que leurs utilisations traditionnelles, ont été étudiées dans deux villes camerounaises (Bafoussam et Yaoundé). Résultats. Quelques préparations culinaires utilisant différentes variétés sont apparues communes dans le sud du Cameroun ; c'est le cas, par exemple, du plantain rôti ou frit, des chips de plantain, du plantain ou de la banane bouillis, et du plantain pilé. Ces plats sont consommés avec diverses sauces ou légumes, et ils peuvent être complétés par d'autres aliments. D'autres préparations trouvées dans ces régions incluent le plantain ou la banane farcis, le porridge de plantain ou de banane et des recettes traditionnelles appelées kondre et malaxé. La préparation de chips et de plantain frit ou rôti est principalement effectuée par des femmes et de jeunes garçons sur les bords des rues; elle permet de diversifier les sources de revenu. Ces diverses transformations et utilisations des bananes et des plantains contribuent aussi bien à la réduction des pertes après récolte qu'à la valorisation de ces produits alimentaires périssables. Conclusion. L'évaluation de la composition nutritive (macro et micro-éléments) de ces aliments, aussi bien que l'impact de leurs préparations culinaires ou que la biodisponibilité des éléments, sont en cours d'étude au laboratoire de Technologie post-récolte du CARBAP ; elle permettra d'apprécier leur contribution dans la lutte contre la malnutrition dans certaines régions du Cameroun.

Cameroun / Musa (bananes) / Musa (plantains) / technologie alimentaire / cuisson / comportement alimentaire / préférence alimentaire / traitement / ingrédient 


\section{Introduction}

Plantains (AAB), as well as other cooking bananas (AAB and ABB), East African cooking bananas, beer bananas (AAA - EA) and dessert banana (AAA, AA) belong to the Musa genus. They are grown in more than 120 countries in the tropical and subtropical regions of the world, mainly for their fruits, but also for their leaves and fibres. In Africa, the total production of bananas and plantains is about $9.6 \mathrm{Mt}$ and, in Cameroon, it is estimated at $1.83 \mathrm{Mt}$ with $35 \%$ of bananas, and $65 \%$ of plantains and other cooking bananas [1].

Bananas and plantains are a major staple food crop for millions of people in Cameroon and contribute significantly to food security. They are widely consumed by the entire population and many different dishes from a wide range of cultural groups are incorporated [2]. Due to the perishable nature of the fruits, the rate of plantain and banana post-harvest losses varies from one region to another according to the organisation of the market chains and modes of consumption. Bananas and plantains are versatile crops in the kitchen as well as being used as raw material for many popular delicacies and snacks. They have many uses in Cameroon according to the socio-cultural behaviour, the eating habits of the populations and the market demand [3]. According to Trèche [4], 69.4\% of plantains and other cooking bananas are used for human consumption while $8.0 \%$ are used for animal feed. Plantain consumption is part of many southern Cameroonian families' customs during events such as weddings or funerals, and in some cases, the presence of plantain in the meal is compulsory [5]. The processing and culinary preparations of bananas and plantains include the presence of many ingredients. Foods from these two products are usually consumed with other food complements. The processed foods are also widely consumed by the whole population in the southern part of the country, and many different dishes can be made from a wide range of banana and plantain cultivars.

Our study was carried out in order to list the varieties of bananas and plantains mostly used by housewives and restaurant dealers and to describe the various culinary preparations used for their transformation, as well as to carry out an inventory of the different recipes derived from bananas and plantains in Cameroon. Our work also aimed at knowing the type, the quantity and the form of the ingredients, as well as the different food complements accompanying various bananaand plantain-based products with respect to the various ethnic groups.

\section{Methods}

Our investigations were held between May and October 2003 in Bafoussam and Yaoundé, two Cameroonian towns located in the southern part of the country and near the main banana and plantain production zones. These localities were also chosen for their population level, ethnic and socio-cultural diversity, as well as their high frequency of consumption of these products. They represent a significant market for producers.

The consumption survey was done through an interview using a tape recorder and a questionnaire that had 18 elements, during which the housewife and the restaurant dealer were identified and asked to name the varieties of banana and plantain mostly used in their family or restaurant. They also had to list the different recipes derived from the transformation of these products and to say where they acquire the plantains and bananas, as well as to give the frequencies of preparation and consumption of their derived food.

During the culinary preparations survey, we described together with the housewife or the restaurant dealer the various methods of transforming bananas and plantains into derived food. This was done through the measurements of the quantities of ingredients using simple food scales, the cooking time using a stopwatch and the quantity of water used during the preparation with a graduated conical flask. Some organoleptic characteristics such as colour, odour and firmness were evaluated through common observations (visual, inhalation, touch, etc.).

During our investigation, we contacted 108 housewives and 20 restaurant dealers aged between 20 and 68 years. They were 
essentially women and young boys from several socio-cultural backgrounds such as Bamiléké (47.2\%), Beti (36.1\%), Sawa and Bassa (9.3\%) and other tribes such as Bayangi, Bakeri and people from the Northern provinces $(7.4 \%)$, who had completed at least primary school level (figures 1-4).

The data collected were then analysed statistically using SPSS statistical software for the determination of the frequencies, means, standard deviation and correlations or associations, respectively, for the quantitative and qualitative variables.

\section{Results}

Plantain in the humid forest zones of Cameroon is highly diversified with a large number of phenotypic forms called cultivars according to Tezenas du Montcel [6]. The four varieties of bananas mostly used for consumption either at home or in restaurants in these towns are 'Gros Michel' (Musa AAA), 'Grande Naine' (Musa AAA), 'Foconah' (Musa AAB) and 'Banane Cochon' (Musa AAA - EA). The most used varieties of plantains (Musa AAB) are 'Elat', 'French Clair', 'Big Ebanga', 'Essong', 'Ebang', 'Kelong Mekintu' and 'One Hand Planty'.

The housewives described the cultivars using the size of the bunch (weight or length), the number of hands per bunch, the size of the fingers in diameter and/or length, the number and appearance of fingers, the skin colour (red, light green, dark green, black, black and white, grey, etc.), the presence of stripes on the skin, and the pulp colour (pink, white or red). Because names of some cultivars may differ from one family to another even in the same ethnic group, many housewives and restaurant owners were not able to name promptly or describe precisely these varieties. They always buy what the sellers on the market offer although they may choose specific plantains or bananas for a particular meal according to their tribe or socio-cultural eating habits.

The populations of the Central and Western provinces of Cameroon consume eight and thirteen recipes derived from the transformation of bananas and plantains at dif-

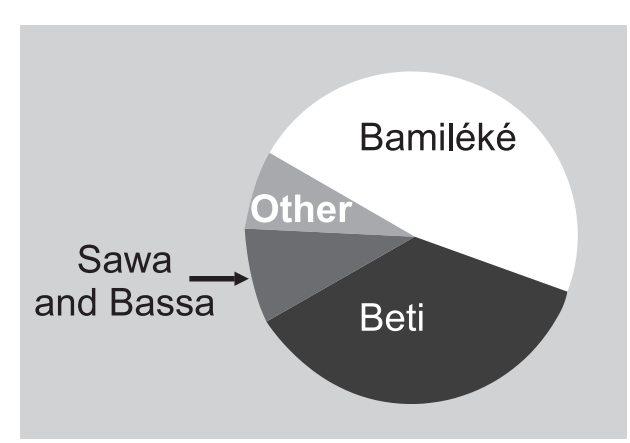

Figure 1.

Socio-cultural backgrounds of the consumers (108 housewives and 20 restaurant owners) contacted during a survey realised in Cameroon to study the food uses of Musa sp.

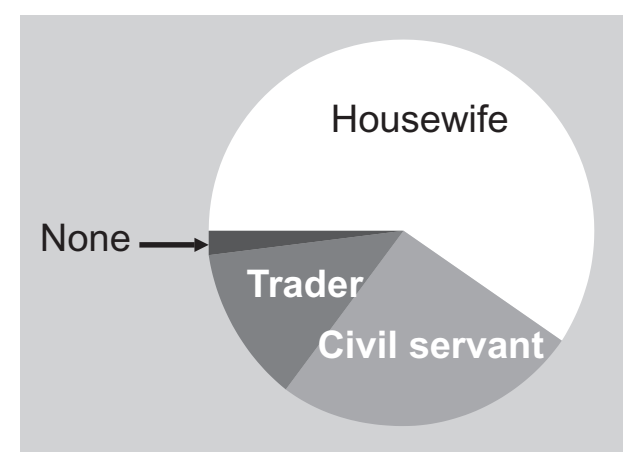

\section{Figure 2.}

Activities of 108 housewives surveyed in Cameroon to study the food uses of Musa sp.

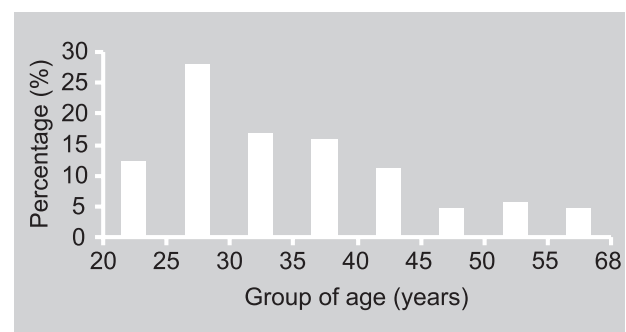

Figure 3.

Age distribution of the consumers (108 housewives and 20 restaurant owners) contacted during a survey realised in Cameroon to study the food uses of Musa sp.

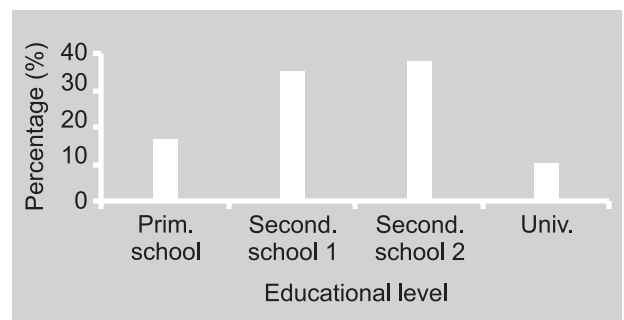

\section{Figure 4.}

Educational level of the people (108 housewives and 20 restaurant owners) contacted during a survey realised in Cameroon to study the food uses of Musa sp. ferent ripeness stages, respectively (table I). Different preparations of these fruits were identified.

\subsection{Boiled pulps}

Boiled unripe or ripe pulps of plantain represent their most important consumption 
Table I.

Some banana- and plantain-based foods consumed in Bafoussam and Yaoundé (Cameroon) and opinions of people surveyed (108 housewives and 20 restaurant owners) regarding their appearance or consumption preference. The appearance and preference were calculated based on the frequencies of citation of the various recipes and their classification according to their preferences by the people contacted during the surveys.

\begin{tabular}{lcc}
\hline Preparation using plantain & Appearance (\%) & Preference (\%) \\
Boiled plantain & 22.1 & 25.0 \\
Plantain paste lined with bean or vegetable & 8.0 & 7.4 \\
Kondre of plantain & 13.5 & 20.4 \\
Fried plantain and plantain chips & 18.4 & 18.5 \\
Bouillon of plantain or Douala-midi & 7.6 & 0.9 \\
Plantain lined with green leafy vegetables & 1.0 & 0.9 \\
Roasted plantain & 4.7 & - \\
Malaxé of plantain & 9.4 & 1.9 \\
Plantain mixed with Egussi paste & 0.6 & - \\
Ntuba or pounded plantain & 9.6 & 21.3 \\
Mielemassesse or sauté of plantain & 1.0 & 1.9 \\
Traditional purée of plantain & 3.9 & - \\
\hline Preparation using banana & & 17.1 \\
Boiled banana & 29.2 & 18.6 \\
Banana paste lined with bean or vegetable & 18.5 & 8.6 \\
Kondre of banana & 6.7 & 44.3 \\
Malaxé of Banana & 33.7 & 2.9 \\
Banana lined with green leafy vegetables & 1.7 & - \\
Traditional banana cake & 5.1 & 1.4 \\
Fritters of ripe banana paste & 1.7 & - \\
Fried or roasted banana & 3.4 & \\
\hline
\end{tabular}

form because it offers the possibility of using preferred or many other food complements. In addition, it is considered as the preferred meal by $1 / 4$ of the people contacted and it is prepared at least three or four times a month. Although almost everyone consumes banana as a dessert fruit, $44.3 \%$ preferred malaxé of banana as a favourite meal because it is a childhood dish and its preparation is not expensive. It is prepared at least once a week in poor families.

\subsection{Dessert fruit}

Banana is consumed as a dessert fruit at the appropriate stage of ripeness, when the peel is totally yellow (stage 6 or 7). This mostly concerns the cultivars Gros Michel, Grande Naine and Foconah, which are sold on the streets by women or young boys. It is a product of economic value.

\subsection{Dried bananas or plantains}

Dried bananas and plantains are produced at the level of small- and medium-scale factories, mainly for exportation to Europe and the USA [7]. The fruits of Foconah, Figue Pomme (Musa AAB), Gros Michel and Pisang Mas (Musa AA) at stages 5 to 7 of ripeness are usually used and seem to be suitable for drying at $65^{\circ} \mathrm{C}$ for about $48 \mathrm{~h}$ or in the sun for 2-3 days.

\subsection{Banana or plantain chips}

To cook banana or plantain chips, the slices of unripe pulp of some cooking bananas 
[Popoulou CMR (AAB), Pelipita (ABB), etc.] and plantains [French Clair, Bâtard, Big Ebanga, etc.] are fried either in refined palm oil at $160-170{ }^{\circ} \mathrm{C}$ for $2-3$ min using an electric fryer or gas at the industrial and restaurant level [8] or in a mixture of refined and unrefined palm oil with onions on a firewood source of energy or gas for 7-10 min by the housewives.

Banana or plantain chips are generally eaten as snack food. They are produced and packed in plastic sachets or in hermetic aluminium sachets at the domestic and smallscale levels as well as at an industrial level for local consumption in Cameroon or for international markets. It is principally a feminine activity, a source of family income.

\subsection{Fried banana or plantain}

The sliced ripe pulps of certain cooking bananas [Topala (AAB), Pelipita (ABB), Popoulou (AAB), Dwarf Kalapua (ABB), etc.] and almost all the varieties of plantain are fried in palm oil or other refined or unrefined vegetable oil at $160{ }^{\circ} \mathrm{C}$ for $5-8 \mathrm{~min}$; they are then eaten with various food complements such as omelette, vegetables, roasted fish, chicken or meat kebab. Fried ripe plantain is a meal well cherished by children. It is usually prepared in restaurants and presented during occasions such as weddings, funerals and cocktails.

\subsection{Roasted banana or plantain}

The ripe or unripe pulps of plantains and some cooking bananas are roasted at home or on the street, then eaten with plums, pears, roasted fish, meat (pork, beef and chicken) and other food complements such as vegetables.

It is a product with economic value, especially for women, young boys and girls in towns, who use charcoal and wire mesh on which the pulps are roasted for $(10 \pm 3) \mathrm{min}$. The price for a roasted banana or plantain ranges between $0.04 €$ and $0.15 €$ and is easily affordable by all classes of people.

\subsection{Boiled banana}

The unripe pulps of almost all dessert bananas as well as unripe or ripe pulps of some cooking bananas are boiled using a gas or kerosene cooker or, locally, using firewood as a source of energy for (43 \pm 13) $\mathrm{min}$ in $(943 \pm 261) \mathrm{mL}$ of water depending on the cultivar or ripening stage of the fruit. This preparation is eaten with various sauces (groundnut, egussi, soybean soup, tomato sauce and Bongo or Ndô soup), various vegetables such as ndole and Amaranthus, fried kidney beans and roasted fish and meat (pork, beef, chicken). It is consumed in high quantity by the Bamileké, and it is sold accompanied with koki by women in many regions of the country.

\subsection{Boiled plantain}

The unripe as well as ripe pulps of plantain are boiled depending on the cultivar or ripening stage of the fruit, sometimes with salt, using a gas or kerosene cooker, or, locally, using firewood as a source of energy for either $(63 \pm 24)$ min with about $(2031 \pm$ 807) $\mathrm{mL}$ of water (2396 $\mathrm{g}$ of unripe pulps) or $(36 \pm 11)$ min with about $(999 \pm 537) \mathrm{mL}$ of water (2 $486 \mathrm{~g}$ of ripe pulps).

It is eaten with various sauces, vegetables, fried kidney beans, koki and roasted fish and meat (pork, beef, chicken) either at home or on the streets. This mode of cooking and eating is quite common in most plantain-producing countries such as Cameroon, Nigeria, Ivory Coast, etc., where it is the major consumption form at home and in restaurants; almost all the varieties of plantains are used by the various tribes for this preparation.

\subsection{Traditional purée of ripe plantain}

To prepare a traditional purée of plantain, $1550 \mathrm{~g}$ of sliced overripe plantain pulps (stage 7 of ripeness or more) are mixed with three other ingredients (13 g of hot pepper, $50 \mathrm{~g}$ of garden egg, $70 \mathrm{~g}$ of unrefined palm oil), before being boiled for $(30 \pm 6) \mathrm{min}$ with $(1017 \pm 375) \mathrm{mL}$ of water and ground in a pot to obtain a mushy or doughy drinkable substance. The people of the Central province of Cameroon make this preparation for the elderly people as breakfast. It is also a method for avoiding losses of overripe plantain pulps. 


\subsection{Malaxé of banana / plantain}

To prepare malaxé of banana, the entire pulps of fingers are mixed with either groundnut, soybean or egussi paste and boiled for $(68 \pm 20)$ min with $(3814 \pm$ $1343) \mathrm{mL}$ of water and other ingredients (4248 $\mathrm{g}$ of unripe pulp of banana, $276 \mathrm{~g}$ of tomato, $18 \mathrm{~g}$ of garlic, $75 \mathrm{~g}$ of onion, $26 \mathrm{~g}$ of Jinja, $9 \mathrm{~g}$ of hot pepper, $84 \mathrm{~g}$ of leek, $24 \mathrm{~g}$ of parsley, $23 \mathrm{~g}$ of celery, $17 \mathrm{~g}$ of Jansan, $389 \mathrm{~g}$ of groundnut paste, $261 \mathrm{~g}$ of unrefined palm oil, 4 Maggi cubes, $52 \mathrm{~g}$ of salt and $196 \mathrm{~g}$ of dried fish). This is the major consumption form of unripe banana because the preparation is said not to be expensive in time or money.

The same process is used for the preparation of malaxé of plantain although the pulps are sliced beforehand to reduce the cooking time $[(54 \pm 12) \mathrm{min}]$ and the amount of water used $(2347 \pm 1158) \mathrm{mL}$. This recipe requires $2237 \mathrm{~g}$ of unripe pulp of plantain, $196 \mathrm{~g}$ of groundnut paste, $80 \mathrm{~g}$ of onion, 3 Maggi cubes, $30 \mathrm{~g}$ of salt, $84 \mathrm{~g}$ of celery, $15 \mathrm{~g}$ of basil, $20 \mathrm{~g}$ of crayfish, $85 \mathrm{~g}$ of dried fish, $10 \mathrm{~g}$ of hot pepper, $90 \mathrm{~g}$ of unrefined palm oil, $15 \mathrm{~g}$ of garlic, $175 \mathrm{~g}$ of tomato and $10 \mathrm{~g}$ of jinja. It is always prepared toward the end of the month in many civil servant families while waiting for the next month's salary.

\subsection{Bouillon of plantain called Douala-midi}

For this bouillon, slices of plantain pulps are mixed with other ingredients (1714 g of unripe pulp of plantain, $73 \mathrm{~g}$ of onion, $16 \mathrm{~g}$ of leek, 3 Maggi cubes, $50 \mathrm{~g}$ of salt, $7 \mathrm{~g}$ of celery, $5 \mathrm{~g}$ of basil, $29 \mathrm{~g}$ of crayfish, $650 \mathrm{~g}$ of dried fish, $10 \mathrm{~g}$ of hot pepper, $334 \mathrm{~g}$ of unrefined palm oil, $14 \mathrm{~g}$ of garlic, $191 \mathrm{~g}$ of tomato and $11 \mathrm{~g}$ of jinja); then, the preparation is boiled for $(37 \pm 20)$ min with $(2657 \pm$ 2 695) $\mathrm{mL}$ of water. The food's name is derived from its short cooking time.

\subsection{Mielemassesse or sauté of plantain}

This recipe needs $2575 \mathrm{~g}$ of sliced unripe plantain pulps and $13 \mathrm{~g}$ of salt, which are boiled with $(3150 \pm 1273) \mathrm{mL}$ of water for $(65 \pm 16) \mathrm{min}$, before being mixed with $130 \mathrm{~g}$ of unrefined palm oil.

This dish, prepared by the Sawa and Bassa people from the Littoral province of Cameroon, is consumed with various sauces, fish or meat during important occasions such as weddings.

\subsection{Kondre of plantain}

To prepare Kondre of plantain, entire plantain pulps are boiled for about (202 \pm 27) min with $(7275 \pm 2752) \mathrm{mL}$ of water and large quantities of meat (goat, pork, beef or chicken) as well as other ingredients (6300 $\mathrm{g}$ of unripe plantain pulp, $40 \mathrm{~g}$ of Jinja, $431 \mathrm{~g}$ of unrefined palm oil, $9 \mathrm{~g}$ of white pepper, $286 \mathrm{~g}$ of refined palm oil, $35 \mathrm{~g}$ of garlic, $8 \mathrm{~g}$ of black pepper, $9 \mathrm{~g}$ of hot pepper, 6 Maggi cubes, $20 \mathrm{~g}$ of celery, $72 \mathrm{~g}$ of salt, $131 \mathrm{~g}$ of onion, $745 \mathrm{~g}$ of tomato, $48 \mathrm{~g}$ of leek, $1780 \mathrm{~g}$ of chicken, $1860 \mathrm{~g}$ of beef, $20 \mathrm{~g}$ of parsley, $14 \mathrm{~g}$ of basil).

The dish, prepared with goat's meat by the Bamiléké people from the Western province, is usually for special occasions such as weddings, funerals and dowry celebrations.

\subsection{Kondre of banana}

To prepare Kondre of banana, entire fruit pulps are also boiled for $(45 \pm 2)$ min with $(3112 \pm 194) \mathrm{mL}$ of water and large quantities of meat (goat, pork, beef or chicken) as well as other ingredients (4425 g of unripe banana pulp, $1300 \mathrm{~g}$ of pork, $1150 \mathrm{~g}$ of beef, $52 \mathrm{~g}$ of salt, $12 \mathrm{~g}$ of garlic, $650 \mathrm{~g}$ of tomato, $109 \mathrm{~g}$ of onion, $38 \mathrm{~g}$ of jinja, $22 \mathrm{~g}$ of jansan, 5 Maggi cubes, $64 \mathrm{~g}$ of basil, $70 \mathrm{~g}$ of celery, $4 \mathrm{~g}$ of thyme, $17 \mathrm{~g}$ of hot pepper, $551 \mathrm{~g}$ of unrefined palm oil).

This dish is preferred by those who do not like plantain because of its hardness or firmness; it is prepared and has been adopted by the people of the Western province for special guests during weddings, funerals and other celebrations.

\subsection{Plantain paste or Ntuba}

Plantain paste is prepared with the unripe pulps of plantains (2 $588 \mathrm{~g}$ ) boiled using 
firewood, a gas cooker or kerosene for about $45 \mathrm{~min}$ with $962 \mathrm{~mL}$ of water; then, the pulps are pounded in a mortar using a wooden piston.

Ntuba, so called by the Beti people of the Central and Southern provinces of Cameroon, is eaten with various sauces (tomato sauce, black pepper soup, groundnut, and especially with $N d \hat{o}$ soup). Elat is the best and specific variety of plantain used for this traditional preparation and it is well appreciated by the elderly people. This meal is a staple food for Beti people. It is similar to Matooke in Uganda, a dish prepared with an East African cooking banana ['Banane Cochon' (Musa AAA-EA)].

\subsection{Banana paste lined with kidney beans or green leafy vegetables}

For this special banana paste, the unripe pulps of cooking bananas and some dessert bananas are first roasted, then boiled before being pounded and mixed with kidney beans or green leafy vegetables. The preparation with kidney beans needs $3250 \mathrm{~g}$ of banana pulp, $2583 \mathrm{~g}$ of cooked kidney beans, $71 \mathrm{~g}$ of salt, $178 \mathrm{~g}$ of onions, $500 \mathrm{~g}$ of unrefined palm oil and $22 \mathrm{~g}$ of hot pepper. The roasted pulps are cooked for about (44 \pm 7 ) min using (1 $290 \pm 268$ ) $\mathrm{mL}$ of water.

Nine ingredients are used for the preparation with vegetables: $943 \mathrm{~g}$ of banana pulp, $1383 \mathrm{~g}$ of cooked green leafy vegetables, $460 \mathrm{~g}$ of unrefined palm oil, $45 \mathrm{~g}$ of salt, $15 \mathrm{~g}$ of hot pepper, $493 \mathrm{~g}$ of tomato, $127 \mathrm{~g}$ of onion, 3 Maggi cubes, $58 \mathrm{~g}$ of crayfish. The banana pulps are boiled with (383 \pm 104) $\mathrm{mL}$ of water for $(40 \pm 5) \mathrm{min}$. The use of kidney beans and leafy vegetables improves significantly improves the nutritive value of this meal, well accepted by children.

Unripe banana paste can be prepared with other recipes:

- For traditional meal (cake), the unripe pulps of cooking bananas ('Banane Cochon') and some dessert bananas ('Foconah') are ground, mixed with other ingredients (1917 g of unripe banana paste, $667 \mathrm{~g}$ of cassava paste, $56 \mathrm{~g}$ of salt, $3 \mathrm{~g}$ of spices, $440 \mathrm{~g}$ of coco yam leaves, $15 \mathrm{~g}$ of hot pepper, $467 \mathrm{~g}$ of unrefined palm oil, $11 \mathrm{~g}$ of black pepper, 5 Maggi cubes, $103 \mathrm{~g}$ of Leloum, $70 \mathrm{~g}$ of crayfish) and $(930 \pm 523) \mathrm{mL}$ of water before being wrapped in banana or plantain leaves, then boiled for a long time [(269 \pm 68$) \mathrm{min}]$.

- For traditional fritters (or Akara banana), the ripe pulp of banana ('Banane Cochon', 'Gros Michel' and 'Grande Naine') is ground, mixed with ingredients (salt, wheat flour, maize flour, cassava paste) and fried in a frying pan over firewood for about $(9 \pm 1) \mathrm{min}$ in unrefined palm oil. This service is done for young primary school children by $10.5 \%$ of the women selling banana- and/or plantain-derived foods on the streets. It is an important source of income and costs from $0.007 €$ to $0.015 €$ for each fried ball.

- For a traditional dish (Achu), the unripe and unpeeled cooking bananas and some dessert bananas $(1550 \mathrm{~g})$ are boiled for about $(65 \pm 7) \mathrm{min}$ with coco yams $(5500 \mathrm{~g})$ using (3250 \pm 354$) \mathrm{mL}$ of water, pounded and the two pastes obtained are mixed with about ( $450 \pm 50) \mathrm{mL}$ of water. The Bamiléké and the people from the Northwestern and Southwestern provinces eat the mixture usually with a yellow or black sauce containing meat, aubergine, fish, etc.

\subsection{Plantain paste lined with kidney beans or green leafy vegetables}

For the preparation of plantain paste lined with kidney beans, $1000 \mathrm{~g}$ of ripe and $3060 \mathrm{~g}$ of unripe fruit of plantain are boiled with $900 \mathrm{~mL}$ of water for $(67 \pm 18) \mathrm{min}$, then pounded with cooked kidney beans (2 $806 \mathrm{~g}$ ), before being mixed with salt (77 g), onions (185 g), unrefined palm oil (650 g) and hot pepper $(15 \mathrm{~g})$ to obtain lined plantain paste also called pilé by its consumers in the Western province.

The preparation of plantain paste lined with leafy vegetables requires $1100 \mathrm{~g}$ of unripe plantain fruit and $2806 \mathrm{~g}$ of green leafy vegetables boiled in the same pot with $(1875 \pm 177) \mathrm{mL}$ of water for $(102 \pm 6) \mathrm{min}$, $365 \mathrm{~g}$ of unrefined palm oil, $71 \mathrm{~g}$ of salt, $9 \mathrm{~g}$ of hot pepper, $315 \mathrm{~g}$ of tomato, $89 \mathrm{~g}$ of onion and 3 Maggi cubes. 


\subsection{Other uses of plantain: Ngomezeck}

Ngomezeck is a traditional dish well appreciated by the elderly people in some regions in the Western province of Cameroon. For this recipe, the unripe slices of plantain pulps (775 g) are mixed with egussi paste $(550 \mathrm{~g}),(587 \pm 124) \mathrm{mL}$ of water and five other ingredients (1 Maggi cube, $4 \mathrm{~g}$ of black pepper, $325 \mathrm{~g}$ dried fish, $60 \mathrm{~g}$ of salt, $10 \mathrm{~g}$ of hot pepper); the mixture is then wrapped in banana or plantain leaves and boiled for $(85 \pm 7) \mathrm{min}$.

\subsection{Banana / plantain flour}

Flour can be obtained from the unripe banana or plantain pulps which are sliced, blanched and dried $\left(<65^{\circ} \mathrm{C}\right)$ before being ground. This flour can be used for the preparation of some banana- and plantain-based products such as fritters (for 10 fritters: $32 \mathrm{~g}$ of flour, $25 \mathrm{~g}$ of butter, $63 \mathrm{~mL}$ of water, $7 \mathrm{~g}$ of sugar, $0.5 \mathrm{~g}$ of salt and $1 \mathrm{egg}$ ) [9] and cakes (100 $\mathrm{g}$ of flour, $60 \mathrm{~g}$ of sugar, $75 \mathrm{~g}$ of skim milk, $40 \mathrm{~g}$ of butter, $3 \mathrm{~g}$ of lemon zest, 3 eggs and $5.5 \mathrm{~g}$ of chemical yeast; the mixture is mixed and then cooked in an oven at $150^{\circ} \mathrm{C}$ for about $40 \mathrm{~min}$ ) [10].

\section{Conclusion}

There are various transformations of bananas and plantains at different stages of ripeness leading to basic foods always eaten with many food complements to fight malnutrition in Cameroon. Statistical analysis showed strongly positive associations between sociocultural ethnics, eating habits and uses of bananas and plantains; moreover, correlations between the different ingredients used during the various culinary preparations also exist.

Our investigation should be continued in other regions or towns near banana and plantain production zones of Cameroon and even in other Central or Western African countries. However, the evaluation of nutrients in fruit and in banana- or plantain- based products, as well as the effect of transformation and culinary techniques on these food constituents, should be taken into account in future research work.

\section{Acknowledgements}

This work was entirely financed by the African Research Centre for Banana and Plantain (CARBAP) in Cameroon. The authors extend sincere gratitude to CTA, which granted the funding for our participation at 'The International Congress on Musa: harnessing research to improve livelihoods', held in Penang (Malaysia), in July 6-9, 2004.

\section{References}

[1] Anon., Bulletin of statistics, Food Agriculture Organisation (FAO) Bull. 2 (2) (2002).

[2] Grimaldi J., Bikia A., Le grand livre de la cuisine camerounaise, Sopecam, Yaoundé, Cameroun, 1985, 258 p.

[3] Dury S., Bricas N., Tchango Tchango J., Temple L., Bikoi A., The determinants of urban plantain consumption in Cameroon, Food Quality and Preference 32 (3) (2002) 81-82.

[4] Trèche S., Importance de I'utilisation des racines, tubercules et bananes à cuire en alimentation humaine dans le monde, Cah. Rech. Dév. 43 (1997) 95-109.

[5] Tchango Tchango J., Bikoï A., Achard R., Escalant J.V., Ngalani J.A., Banana plantain: post-harvest operations, in: Mejia D., Lewis B., Bothe C. (Eds.), Postharvest compendium, chapter XIV, html doc., Post-harvest Management Group AGSI-FAO, Rome, Italy, 2000, http://www.fao.org/inpho/content/compend/ text/ch14-01.htm.

[6] Tézenas du Montcel H., Variabilité dans l'ensemble des cultivars de plantains de la collection d'Ekona au Cameroun, Fruits 38 (4) (1983) 246-255.

[7] Tchango Tchango J., Ngoh Newilah G., Overview of Musa utilisation in Africa, in: Int Sem. Assessing the Opportunities for Developing and Diversifying Markets for Banana 
and Banana-based Products in Sub-Saharan Africa (SSA), February 2-6, 2004, Kampala, Uganda, Asareca, Entebbe, Uganda (in press).

[8] Lemaire H., Reynes M., Ngalani J.A., Tchango Tchango J., Guillaumont A., Aptitude à la friture de cultivars de plantains et bananes à cuire, Fruits 52 (4) (1997) 273-282.
[9] Ngalani J.A., Crouzet J., Utilisation de la farine de banane plantain dans la fabrication de pains, biscuits et farines instantanées, Cah. Agric. 4 (1995) 61-64.

[10] Tchango Tchango J., Farine de plantain : préparation et utilisation en pâtisserie et dans la formulation d'aliments infantiles, CARBAP, Note tech. / doc., Ngombé, Cameroun, 2003, $4 \mathrm{p}$.

Transformaciones y utilizaciones alimenticias de bananos y de plátanos en Camerún.

Resumen - Introducción. En el sur de Camerún, los bananos y los plátanos (Musa) desempeñan un papel importante en el régimen alimenticio de las poblaciones. Existe una gran diversidad de preparación de estos productos en función de las costumbres alimenticias de los consumidores. Nuestro estudio pretendió hacer un inventario de las variedades de bananos y de plátanos más empleados por las amas de casa y por los restauradores. Asimismo, pretendió describir las distintas preparaciones culinarias utilizadas para la transformación de sus frutos. Métodos. En dos ciudades cameruneses se estudiaron las transformaciones de los bananos y de los plátanos y las técnicas culinarias que incluyen tanto la naturaleza de los ingredientes utilizados como las cantidades, así como sus utilizaciones tradicionales. Resultados. Algunas preparaciones culinarias que utilizaban distintas variedades parecieron ser comunes en el sur de Camerún; es el caso, por ejemplo, del plátano asado o frito, de las patatas fritas a base de plátanos, bananos y plátanos hervidos, y del plátano machacado. Estos platos se consumen con distintas salsas o verduras, y se pueden completar con otros alimentos. Otras preparaciones encontradas en estas regiones incluyen el banano o el plátano rellenos, el porridge de banano o de plátano; y, recetas tradicionales llamadas kondre y malaxé. Principalmente las mujeres y los muchachos en el borde de las calles preparan patatas fritasa base de plátanos y plátanos fritos o asados, lo que permite diversificar las fuentes de ingresos. Estas diversas transformaciones y utilizaciones de los bananos y de los plátanos contribuyen tanto a la reducción de las pérdidas después de las cosechas, como a la valorización de estos productos alimenticios perecederos. Conclusión. La evaluación de la composición nutritiva (macro y microelementos) de estos alimentos, así como el impacto de sus preparaciones culinarias o la biodisponibilidad de los elementos, están en proceso de estudio en el laboratorio de tecnología después de cosecha del Carbap. Además permitirá valorar su contribución en la lucha contra la desnutrición en algunas regiones de Camerún.

Camerún / Musa (bananos) / Musa (plátanos) / tecnología poscosecha / tecnología de alimentos / cocción / hábitos alimentarios / preferencias alimentarias / procesamiento / ingredientes 